\title{
On the Lower Cambrian biotic and geochemical record of the Hetang Formation (Yangtze Platform, south China): evidence for biogenic silica and possible presence of Radiolaria
}

\author{
LEI ZHANG ${ }^{1,2}$, TANIEL DANELIAN ${ }^{2, *}$, QINGLAI FENG ${ }^{1}$, THOMAS SERVAIS ${ }^{2}$, NICOLAS TRIBOVILLARD ${ }^{2} \&$ \\ MARTIAL CARIDROIT ${ }^{2}$ \\ ${ }^{1}$ China University of Geosciences (Wuhan), Department of Earth Sciences, Wuhan, PR China \\ ${ }^{2}$ Department of Earth Sciences, University of Lille 1, Géosystèmes (UMR 8217 CNRS/Lille1), Bât SN5, 59655 Villeneuve d'Ascq cedex, France \\ *Corresponding author (e-mail: taniel.danelian@univ-lille1.fr)
}

\begin{abstract}
Research on Lower Cambrian siliceous sedimentary rocks is important for understanding the origin and early involvement of polycystine Radiolaria in the silica cycle. During our study, thin sections and HF acid processing of black cherts and shales from the Hetang Formation that crops out in the Xintangwu section (west Zhejiang Province, south China) were made. We report on the presence of siliceous spherical microfossils (possibly Radiolaria) associated with sponge spicules and acritarchs. Their size and the presence of residual spines on some spherical siliceous microfossils observed in both residues and thin sections of cherts from the top of Member ' $a$ ' of the Hetang Formation argue for the possible presence of radiolarians. Based on the Small Shelly Fossil assemblages reported in previous studies, this interval should be considered as Qiongzhusian (Atdabanian-Early Botomian) in age. Finally, the values of the $\mathrm{Ge} / \mathrm{Si}$ ratio measured on black cherts of the Hetang Formation point to a biogenic origin of the silica. J. Micropalaeontol. 32(2): 207-217, July 2013.
\end{abstract}

KEYWORDS: Lower Cambrian, Radiolaria, biogenic silica, Yangtze Platform, Hetang Formation

\section{INTRODUCTION}

The Lower Cambrian Hetang Formation in south China consists essentially of black carbonaceous shales and contains one of the oldest available records of siliceous microfossils. The presence of individual sponge spicules has been reported in a number of papers (e.g. Zhou \& Jiang, 2009) and Xiao et al. (2005) discussed one of the oldest and best preserved articulated sponge assemblages. The presence of Radiolaria in the Hetang Formation has been reported by Braun \& Chen (2003) and Braun et al. (2007a), but this claim remains controversial (see Maletz, 2011). Identifying the earliest record of polycystine radiolarians is undoubtedly important in the context of the rise of siliceous biomineralization in eukaryotic lineages (see Danelian \& Moreira, 2004) and its impact on the evolution of the silica cycle (Maliva et al., 1989; Siever, 1992; Racki \& Cordey 2000). Given that polycystine radiolarians are one of the earliest Rhizarian lineages (Blair Hedges et al., 2001; Bass et al., 2005), their oldest fossil record is also important for both calibration of the Rhizarian phylogenetic tree and improved understanding of their early evolutionary history. In addition, the presence of siliceous pelagic sedimentary rocks (organic-rich black siliceous shales and cherts) in the Lower Cambrian Hetang Formation is of interest because it requires understanding of the origin of silica in dysoxic/anoxic environments (Zhou \& Jiang, 2009). The Upper Cambrian Burubaital radiolarian cherts, which accumulated in an open oceanic equatorial depositional environment (Tolmacheva et al., 2001), represent, to our knowledge, one of the oldest radiolarian siliceous sedimentary sequences known so far. Opinions diverge regarding the origin of the abundant silica preserved in the Hetang Formation. Some authors argue for hydrothermal vents as being at the origin of the silica (Murowchick et al., 1994; Mao et al., 2001; Yang et al., 2005), while others favour a biogenic origin (sponges, Radiolaria; Braun et al., 2007b).

The Xintangwu section is one of the best known Lower Cambrian sections of the Yangtze Platform (Steiner et al., 2003,
2007). Given that Braun et al. (2007a) claimed the presence of Radiolaria in this section, we revisited it with the main purpose of testing their possible presence. We also attempted to provide new biostratigraphic constraints based on acritarchs. Although the recovered acritarchs do not provide this direct constraint they do complete our understanding of the biotic components preserved in this formation. Finally, new geochemical data on the $\mathrm{Ge} / \mathrm{Si}$ ratio argue in favour of a biogenic origin for the siliceous rocks in the Hetang Formation.

\section{GEOLOGICAL AND STRATIGRAPHIC FRAMEWORK}

The Palaeozoic sedimentary sequence of the Yangtze Platform accumulated on the continental crust of a microplate that has existed since at least $3.8 \mathrm{Ga}$ ago (Jiao et al., 2009). During the Ediacaran, shallow-water carbonate sedimentation, formed essentially by stromatolites, was widespread on the Yangtze Platform.

The Hetang Formation accumulated at the southern and southeastern margin of the Yangtze platform (Fig. 1a) and crops out mainly in western and northern Zhejiang Province (Yang et al., 2008) (Fig. 1b herein). It displays important lateral thickness variation, ranging between $c .20 \mathrm{~m}$ and several hundred metres, reflecting increasing basin water-depth westwards. It was first described by $\mathrm{Lu}$ et al. (1955) in the Hetang country, north of Jiangshan city (Zhejiang Province; Figs 1b, c), as siliceous black shales displaying a basal $20 \mathrm{~m}$ thick organic-rich stonecoal (flammable mudstone) sequence with black cherts (Member ' $a$ '). Later studies distinguished a number of different lithostratigraphic units, such as the c. $0.5 \mathrm{~m}$ thick 'chert unit' at the base of Member 'a', which is composed mainly of black cherts, phosphorites and occasional pelitic limestones in western Zhejiang (Yue \& He, 1989; He \& Yu, 1992) (Fig. 2). Its top is marked by fossiliferous phosphatic carbonates containing Small Shelly Fossils (SSF) which can be correlated with the Lower Meishucunian Protohertzina anabarica - Kayangites novalis assemblage zone (Steiner et al., 2003, 2007). The general consensus is that the Hetang Formation 


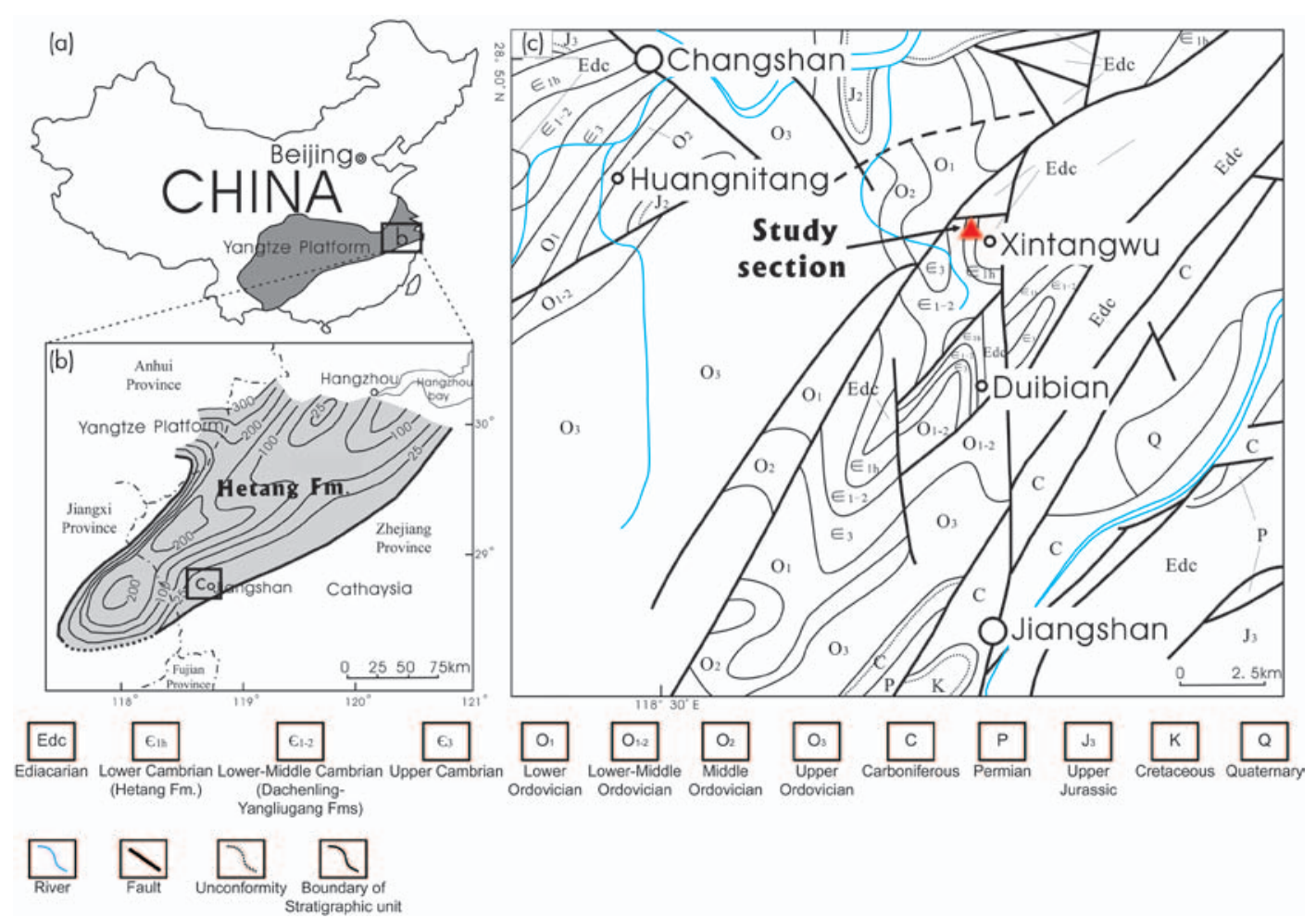

Fig. 1. (a) Map of China, including the current geographical distribution of sedimentary sequences that are part of the Yangtze Platform. (b) Isopach map of the Hetang Formation in west Zhejiang, south Anhui, and North Jiangxi province (after Xue \& Yu, 1979). (c) Simplified geological map of the Jiangshan area, including the location of the Xintangwu section (after Peng et al., 2009).

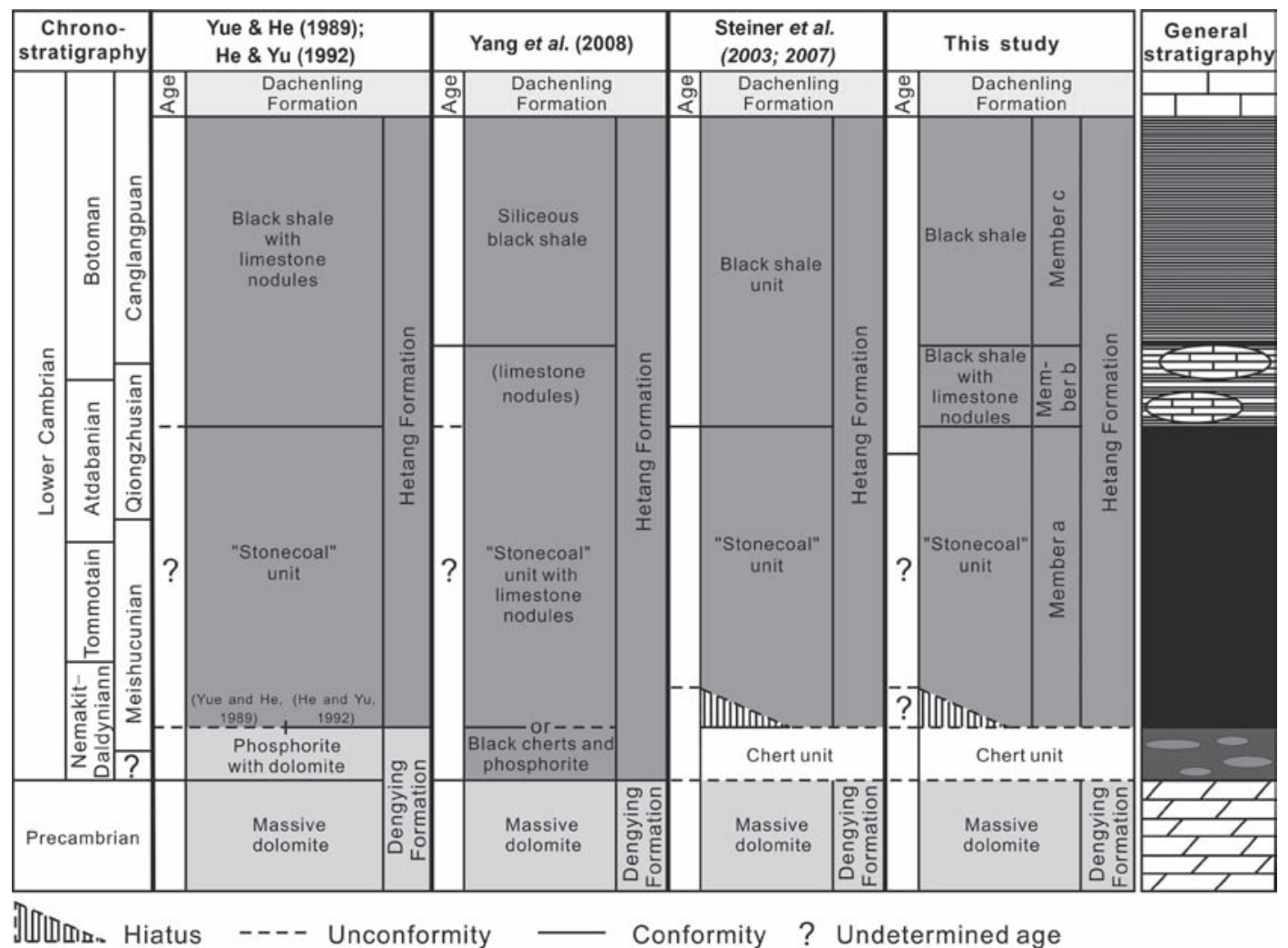

Fig. 2. Synthesis of the various lithostratigraphic subdivisions and chronostratigraphic assignments of Lower Cambrian sedimentary sequences (including the Hetang Formation) throughout the SW margin of the Yangtze Platform. 
The Lower Cambrian biotic and geochemical record of the Hetang Fm., China

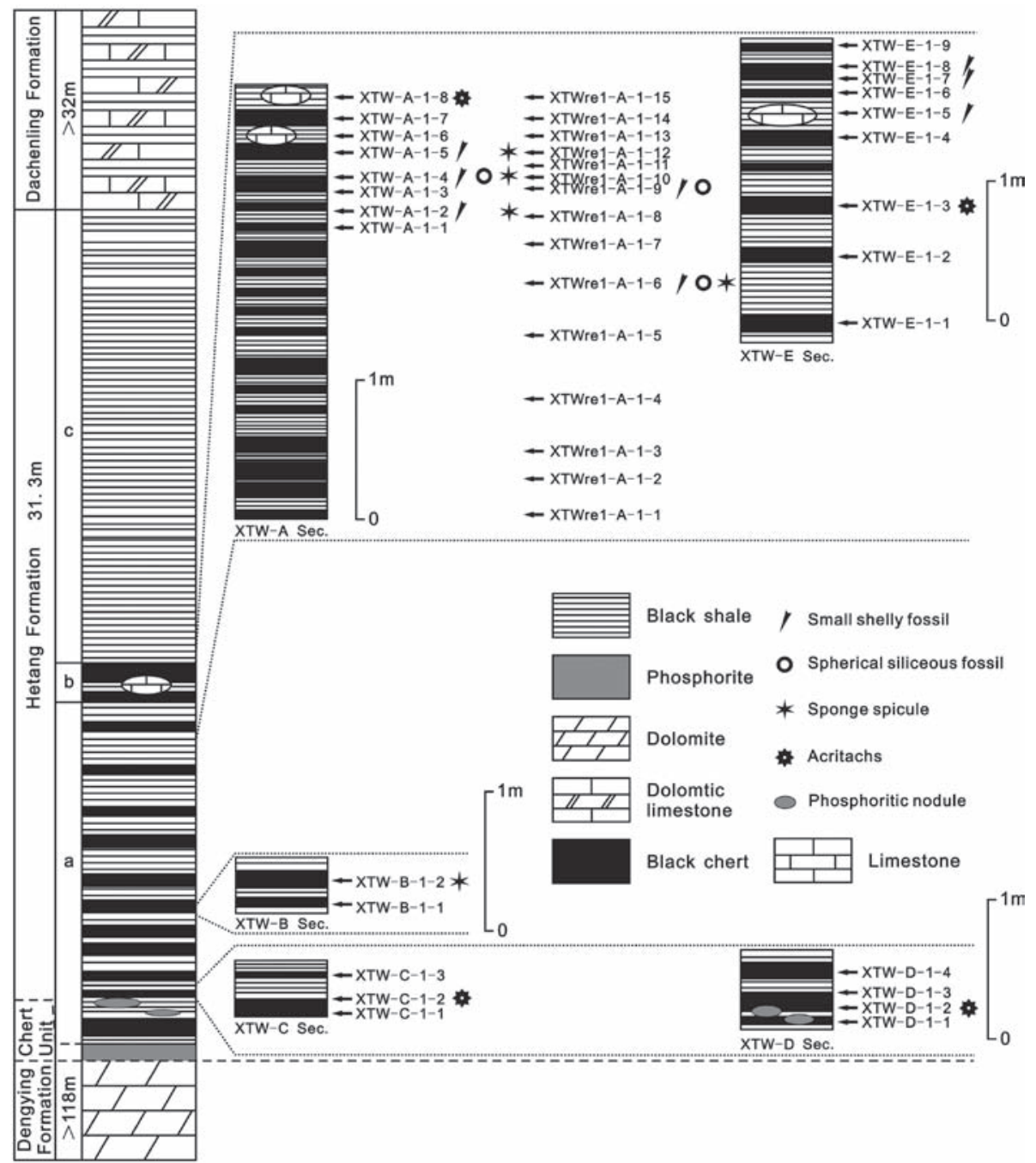

Fig. 3. Stratigraphic column of the Xintangwu section, including the sampled levels and different types of microfossils recovered.

cropping out in the Jiangshan area can be divided into three members: (i) Member ' $a$ ' of black shale, stonecoal layers with a few intercalations of thin-bedded sparitic limestone; (ii) Member ' $b$ ' of black shale interbedded with thin-bedded black cherts that contain carbonate concretions towards the top of the sequence; an interval with Jiangshanodus-Kijacus-type arthropod spines characteristic of the Qiongzhunsian is known from this member (Steiner et al., 2003, 2007); (iii) Member 'c' of black siliceous shales.

\section{THE STUDIED SECTION}

The Xintangwu Section $\left(28.823^{\circ} \mathrm{N}, 118.622^{\circ} \mathrm{E}\right)$ is situated at the SE margin of the Yangtze Platform, Zhejiang Province (Fig. 1). In this locality, the Hetang Formation is $25.5 \mathrm{~m}$ thick (Fig. 3). The exposure of beds in this section is not ideal because of vegetational cover. However, one can recognize overall the main lithological characteristics of the Hetang Formation. Only some small abandoned quarries, which were created to excavate the stonecoal, allow precise stratigraphic observations. Two parallel quarries, situated towards the base of the Hetang Formation, allow observation of the black shales with phosphoritic nodules. Towards the upper part of the stonecoal sequence an interval with carbonate nodules can be observed. Forty- one samples were collected from members ' $a$ ' and ' $b$ ' of the Hetang Formation exposed at 4 closely adjacent sites (Fig. 3).

\section{SEDIMENTARY FABRIC}

Polished thin sections were made of all the samples collected from the Hetang Formation. Observations were conducted with the help of a polarizing microscope, a field emission scanning electron microscope (SEM) and Raman spectroscopy. Microfacies analysis reveals the presence of numerous laminated beds, rich in wavy quartz, organic matter, pyrite framboids and diagenetic pyrite crystals (Zhou \& Jiang, 2009). In some samples pyrite is organized in distinct beds. Some samples are very rich in microcrystalline quartz, with the quartz grain size being smaller than $5 \mu \mathrm{m}$. X-ray diffraction analyses established that associated minerals are mainly barite and pyrite and subordinate clay minerals, such as muscovite, microcline and rarely gypsum.

\section{SILICEOUS MICROFOSSILS}

Analytical procedure

Siliceous microfossils were obtained from siliceous samples that were immersed in $2-5 \% \mathrm{HF}$ solution for $12 \mathrm{~h}$ at ambient temperature. 


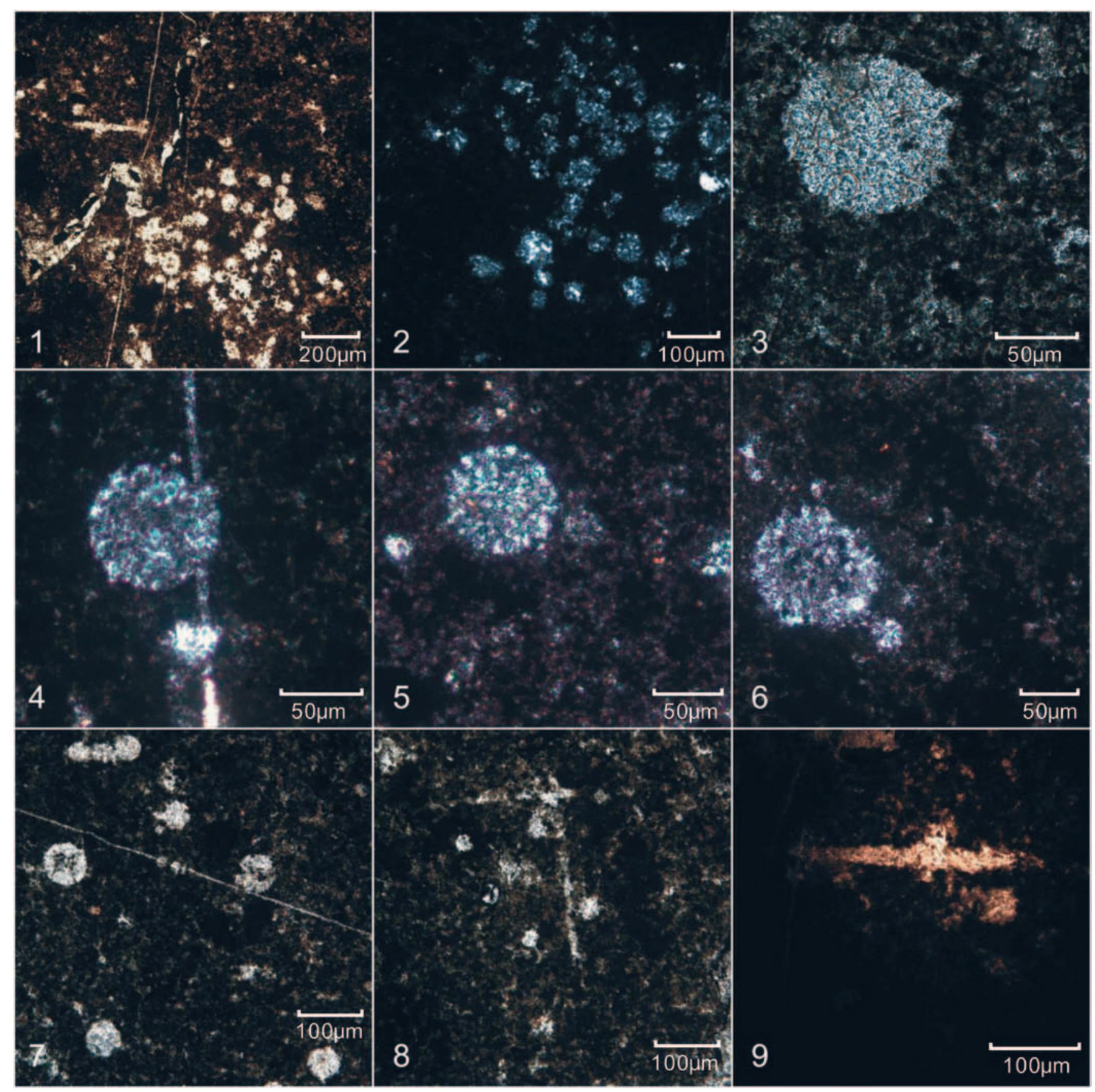

Explanation of Plate 1. Spherical siliceous fossils and sponge spicules observed on thin-section preparations. All figures come from sample XTW A-1-4, situated at the top of Member 'a' (see Fig. 3). figs 1, 2, 7. Scatter of spherical fossils: 1, 7, under polarized light; 2, under orthogonally polarized light. figs 3-6. Enlargement of specimens: 3, under polarized light, 4-6, under orthogonally polarized light. figs 8, 9. Sponge spicules under polarized light.

Residues were sieved through a $63 \mu \mathrm{m}$ mesh and dried for examination under a binocular microscope. The containers holding the samples were refilled with new HF solution and the whole process was repeated several times.

\section{Results}

Among the 41 samples analysed, siliceous microfossils were observed in 13 samples, both in thin section and residues. More particularly, sample XTW A-1-4, situated at the top of Member ' $\mathrm{a}$ ', about $0.5 \mathrm{~m}$ below the layer containing bituminous limestone concretions (Member 'b'), yielded abundant spherical siliceous microfossils very similar to the ones illustrated by Braun \& Chen (2003). The fossils we report have a relatively uniform spherical/ ellipsoidal shape, they appear bright and clean, and they are clearly distinguishable from the background sediment of dark black chert, rich in carbon content (Pl. 1, figs 1,2$)$. A thin crust is 
The Lower Cambrian biotic and geochemical record of the Hetang Fm., China
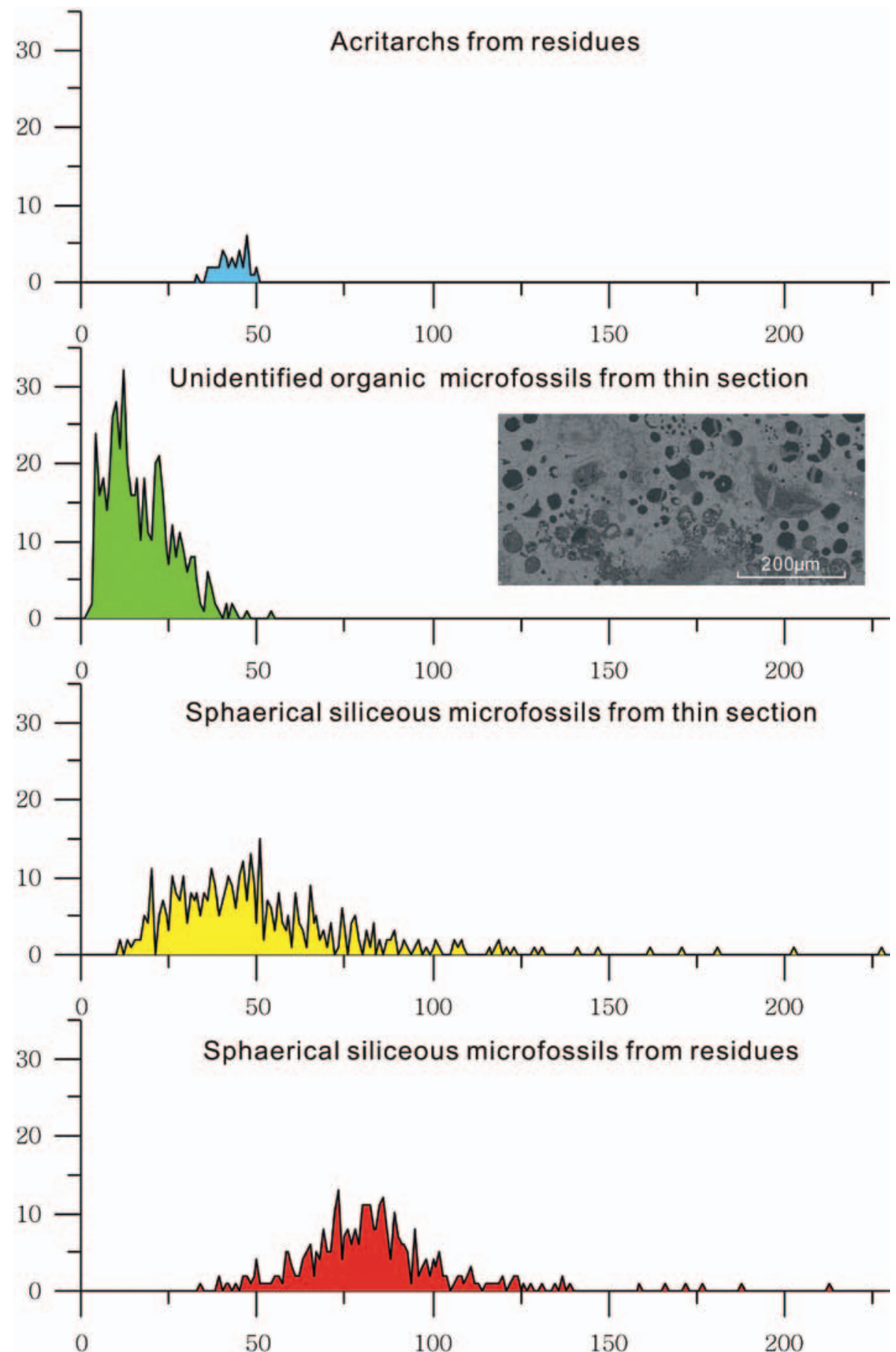

Fig. 4. Frequency diagram of the diameters measured on the various spherical microfossils (siliceous, organic) observed in both acid residues and thin sections. The SEM image illustrates unidentified organic spherical microfossils, possibly acritarchs, on the surface of an uncovered thin section of sample XTW E-1-3.

visible on the margin of the sphere on some specimens (Pl. 1, fig. 4). Some of them appear to have spines of unequal size (Pl. 1, fig. 3). Observation under the cross-polarizer reveals that these microfossils are composed of fine grains of quartz and they have a radial extinction texture. Results of Raman analysis also confirm that all these fossils are made of quartz. Backscattered electron (BSE) imaging was used to check the elements of these spherical microfossils; both microfossils and matrix appear fairly similar, the only difference being the organic carbon content present in the sediment matrix. Analysis of growth of different generations of quartz grains preserved in the siliceous microfossils reveals no difference between their fine-grain shell and their relatively coarser-grain interior: these two sizes of quartz grain appear to have been developed simultaneously. 


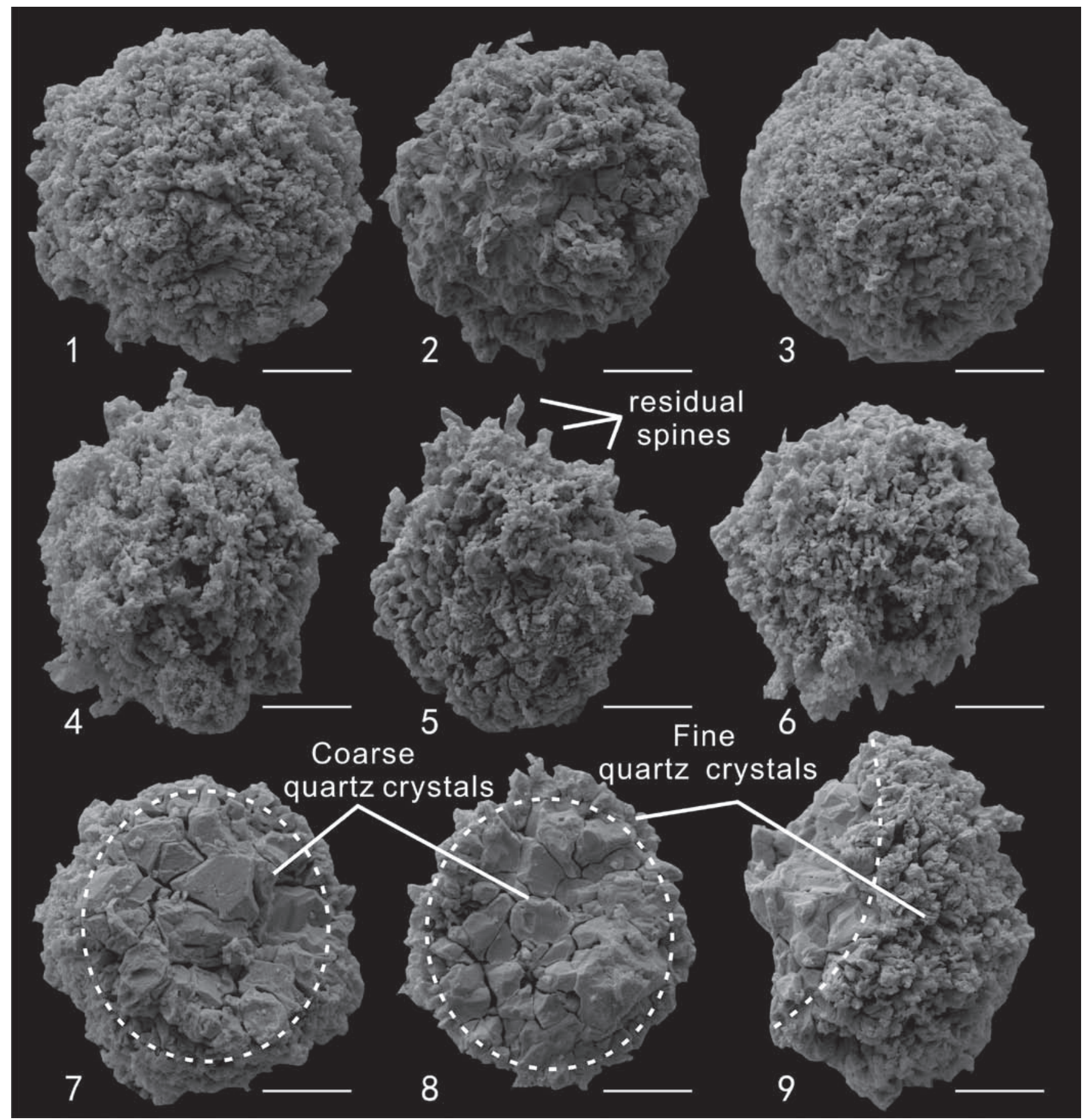

Explanation of Plate 2. Scanning electron micrographs of the spherical siliceous fossil specimens from the Xintangwu section, sample XTW A-1-4. Scale bar $20 \mu \mathrm{m}$ for all specimens. fig. 5 displays possible residual spines. Broken specimens illustrated in figs $7-9$ show that their interior is filled with coarser crystals of quartz.

More than 500 spherical siliceous microfossils were recovered from the same sample after HF processing. Their size and shape are similar to specimens observed from thin sections. Regrettably, all siliceous microfossils are heavily recrystallized, including some recovered siliceous sponge spicules. More than 400 SEM images were made but the lattice shell and inner structure are hard to distinguish (Pl. 2, fig. 4). Short residual spines appear to be present on the surface of a few specimens (Pl. 2, figs 5, 6). Cross-sections of some naturally broken specimens confirmed thin section observations, as they reveal that the inner part of these spherical microfossils is filled with larger quartz grains, while their outer layer is made of finer quartz grains (Pl. 2, figs 7-9). 


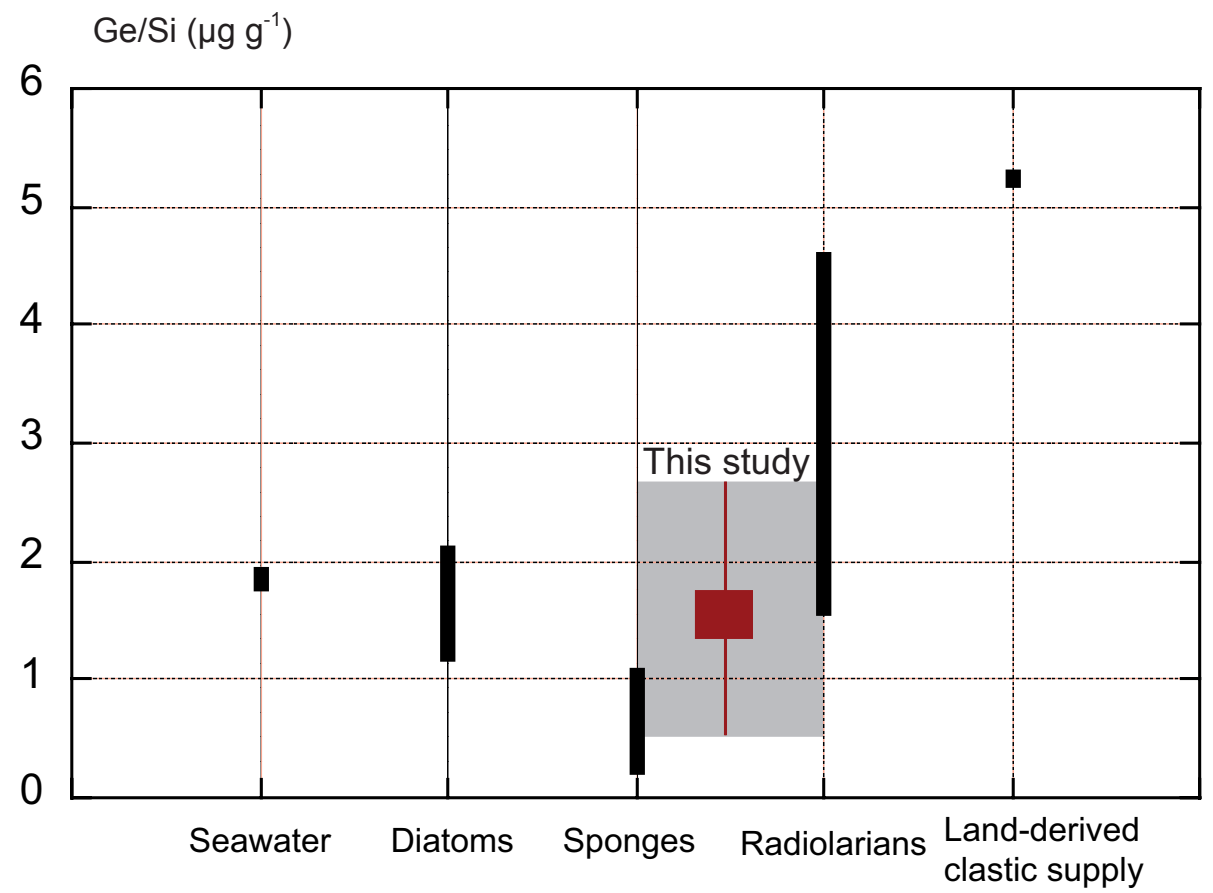

Fig. 5. Values of the Ge/Si ratio (expressed in $\mu \mathrm{g} \mathrm{g}^{-1}$ ) for the studied samples compared to those of biogenic origin, seawater and average land-derived clastic fluxes (Tribovillard et al., 2011).

\section{PALYNOLOGY}

\section{Analytical procedure}

Eight samples were processed for palynological investigations. 10$50 \mathrm{~g}$ of each sample was prepared according to standard palynological methods. After treatment with $\mathrm{HCl}(33 \%)$ and $\mathrm{HF}(40 \%)$, samples were neutralized with distilled water between acid treatments. The residues were filtered through $50 \mu \mathrm{m}$ and $15 \mu \mathrm{m}$ nylon sieves, thus yielding $>50 \mu \mathrm{m}, 15-50 \mu \mathrm{m}$ and $<15 \mu \mathrm{m}$ fractions from each sample. The residues were studied using light microscopy.

\section{Results}

Only a few investigations report Cambrian acritarchs from China (see Li et al., 2002 for a complete list of references), most of them dealing with material from the Yangtze Platform. Most of these papers reported sphaeromorph (round morphotypes) or micrhystrid acritarchs (small morphotypes with short spines). During our study, numerous acritarchs were obtained after HF processing (Pl. 3), but only a few are well preserved. They mostly belong to the sphaeromorphs and could be attributed to genera such as Leiosphaeridium or Lophosphaeridium. Such sphaeromorph acritarchs of this size (about $25-40 \mu \mathrm{m}$ ) are very common in Lower Cambrian sediments. They do not have any biostratigraphical or palaeobiogeographical significance, but they are typical of deeper-water environments, as illustrated in a number of palaeoecological studies (e.g. Lei et al., 2012). Unidentified organic spherical microfossils can be observed with the SEM on thin sections (Fig. 4). Xue \& Yu (1979) regarded them as belonging to both acritarchs and small algae, such as Palaeomicrocystis, Entophysalidaceae and Michrystridium.

\section{GEOCHEMISTRY}

\section{Analytical techniques}

The geochemical analyses of 10 samples ( 5 of them also processed for palynological analysis) from the Xintangwu section were performed by ICP-AES (major and minor elements) and ICP-MS (trace elements) at the Spectrochemical Laboratory (SARM) of the Centre de Recherches en Pétrographie et Géochimie of Vandœuvreles-Nancy (Centre National de la Recherche Scientifique). The samples were prepared by fusion with $\mathrm{LiBO}_{2}$, followed by $\mathrm{HNO}_{3}$ dissolution. Precision and accuracy were both better than $1 \%$ (mean $0.5 \%$ ) for major-minor elements and $8 \%$ for trace metals, as checked by international standards and analysis of replicate samples (Carignan et al., 2001).

\section{Results}

The Ge/Si ratio of the examined samples ranges between 0.46 and $2.69 \mu \mathrm{gg}^{-1}$ (Table 1), with a mean ratio equal to $1.5 \mu \mathrm{gg}^{-1}$. These values fall within the range corresponding to the opalsecreting organisms and plot far from the value attributed to the average clastic supply (Fig. 5; Tribovillard et al., 2011). We interpret these results as an indication that the cherts originate from biogenic silica, implying either sponges alone or both sponges and radiolarians.

\section{DISCUSSION}

The Late Neoproterozoic-Cambrian is a critical time interval for the silica cycle, since it started being influenced by silica biomineralizing organisms, such as the Silicisponges and polycystine Radiolaria (Maliva et al., 1989; Siever, 1992; Racki \& Cordey, 2000).

The southern margin of the Yangtze Platform preserves the Lower Cambrian sedimentary record of pelagic environments, following a tectonic deepening of a previously shallow-water Ediacaran carbonate platform (Steiner et al., 2003). Widespread preservation of organic-rich sediments and framboidal pyrite in the black shales (Zhou \& Jiang, 2009, and our own observations) point to a sedimentary environment that was anoxic for most of the time, although it was interrupted occasionally by intervals of 

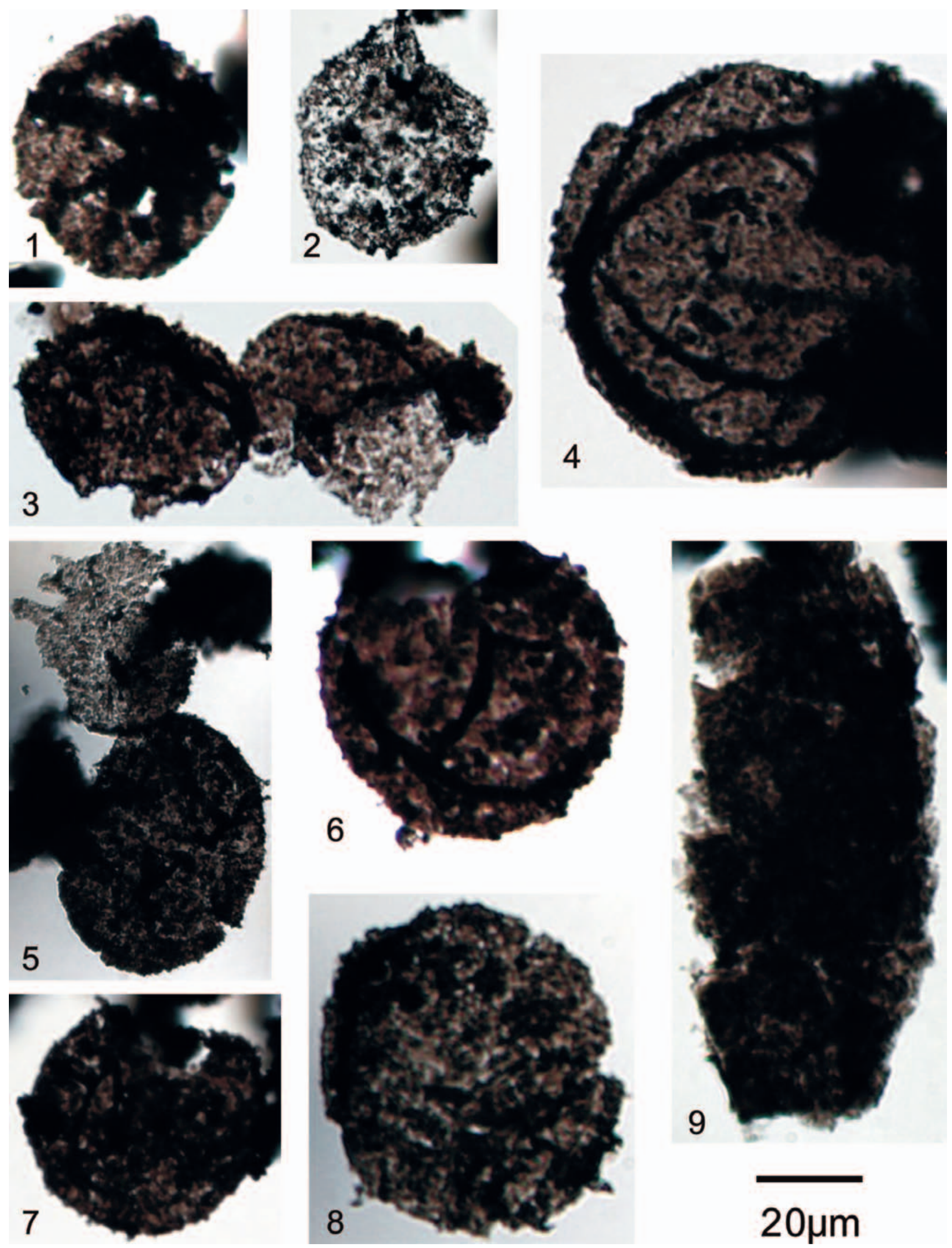
The Lower Cambrian biotic and geochemical record of the Hetang Fm., China

Table 1. Values of the $\mathrm{Ge} / \mathrm{Si}$ ratio on the 10 selected samples from the Xintangwu section.

\begin{tabular}{ll}
\hline Samples & $\mathrm{Ge} / \mathrm{Si}$ \\
\hline XTW-A-1-2 & 0.678 \\
XTW-A-1-4 & 0.520 \\
XTW-A-1-7 & 0.463 \\
XTW-B-1-2 & 0.719 \\
XTW-C-1-2 & 2.366 \\
XTW-C-1-3 & 2.223 \\
XTW-D-1-2 & 1.825 \\
XTW-E-1-1 & 1.641 \\
XTW-E-1-8 & 2.694 \\
XTW-E-1-9 & 1.862
\end{tabular}

oxygenation (indicated by the presence of sponge spicules; see discussion in Zhou \& Jiang, 2009). The sedimentary fabric observed in the studied samples suggests accumulation under relatively quiet hydrodynamic conditions.

The values obtained for the $\mathrm{Ge} / \mathrm{Si}$ ratio allow us to conclude that the silica of the siliceous rocks studied in the present paper is of biogenic origin. However, based on the $\mathrm{Ge} / \mathrm{Si}$ value alone, it cannot be determined whether sponges or radiolarians were the main source of silica (both may have operated in conjunction).

Radiolarians reported by Braun et al. (2007a) come from a carbonate nodule which, based on the lithostratigraphic information they provided (i.e. see their fig. 1), comes from the unit Member ' $b$ ' of black shales and cherts with carbonate concretions. In addition to a few 'lattice fragments' reported after treatment with acetic acid, they also illustrated a fairly complete specimen, for which doubts about contamination from Upper Ordovician material have been raised by Maletz (2011). Indeed, the single specimen illustrated by Braun et al. (2007a, fig. 3) does not appear to share any resemblance with confirmed Cambrian Radiolaria. However, it is worth noting that most of Braun's illustrated material comes from a stratigraphic level that is close to the one in which we observed spherical microfossils that most closely resemble Radiolaria (i.e. sample XTW A-1-4; P1. 1, fig. 3; Pl. 2, figs 4-5). Braun et al. (2007a) considered this interval as coeval to the Anabarites-Protohertzina Zone (Meiscucunian age) based on an unpublished excursion guide, but, as discussed above, this interval is, in reality, younger in age and, according to the data of Steiner et al. (2003), can be correlated with the Qiongzhushian (Atdabanian in terms of the Siberian stages). Thus, it is only one stage older than the Botomian radiolarians found in the Altai Mountains in Siberia (Obut \& Iwata, 2000; Pouille et al., 2011; Korovnikov et al., 2013).

Figure 4 attempts a size comparison of all spherical microfossils observed in our material; these consist of 39 specimens of acritarchs (isolated specimens obtained from residues), 483 unidentified organic spherical microfossils based on thin section observations, 424 spherical siliceous microfossils based also on thin section observations, and 341 spherical siliceous microfossils recovered after HF processing.

- Specimens of confirmed acritarchs display a relatively stable size range, varying between 25 and $52 \mu \mathrm{m}$.

- The size of the majority ( $82 \%$ ) of the unidentified organic spherical microfossils ranges between 6 and $30 \mu \mathrm{m}$, with an uppermost limit at about $55 \mu \mathrm{m}$.

- The diameter of the spherical siliceous microfossils observed in thin sections ranges between 11 and $228 \mu \mathrm{m}$, with the majority of them $(81.5 \%)$ falling between 26 and $75 \mu \mathrm{m}$.

- The diameter of the spherical siliceous microfossils recovered after HF processing ranges between 34 and $213 \mu \mathrm{m}$, with the majority of them ( $82 \%)$ falling between 58 and $107 \mu \mathrm{m}$.

Therefore, a large part of the siliceous microfossils in our material is larger than the entire population of organic-walled microfossils.

It is worth comparing our measured specimens with the size range of the few Cambrian radiolarians with a spherical shape known from the literature (Dong et al., 1997; Won \& Below, 1999; Obut \& Iwata, 2000; Pouille et al., 2011). The size of most of them is rather large as compared to our material, ranging between 150 and $655 \mu \mathrm{m}$. Indeed, only a very small fraction (c. $1.5 \%$ ) of our material appears to be larger than $150 \mu \mathrm{m}$. However, smaller spherical radiolarian species are also known, as is the case of Spongomassa nannosphaera Won, described from the Middle Cambrian of Australia, the shell diameter of which varies between 93 and $130 \mu \mathrm{m}$.

It is interesting to note that the radiolarian specimens reported by Obut \& Iwata (2000) from the Botomian (Lower Cambrian) levels of the Altai Mountains (Siberia) are even smaller in size. Indeed, the shell diameter of species Archaeocenosphaera muricata Obut \& Iwata ranges between 80 and $100 \mu \mathrm{m}$. Some of our illustrated specimens fall in this size range (i.e. Pl. 1, figs 3-5) or they are even larger (P1. 1, fig. $6 ; 116 \mu \mathrm{m})$. Altogether, $53 \%$ of the siliceous microfossils yielded after HF processing and c. $10 \%$ of those observed in thin section display a diameter larger than $80 \mu \mathrm{m}$. Without claiming that the above species can be identified in our material, it is interesting to note that $A$. muricata is known as a single hollow shell with very short by-spine like protuberances and that the two generations of quartz crystals (fine quartz on the outer part v. coarse crystals in the interior) argue for a hollow spherical test.

\section{CONCLUSIONS}

(1) Based on the Small Shelly Fossil stratigraphic record of Steiner et al. (2003), the black shale level of the Hetang Formation from which Braun et al. (2007a) reported Cambrian Radiolaria (Member ' $b$ ', which contains limestone concretions) should be considered as Qiongzhusian (Atdabanian-lower Botomian), rather than Meishucunian, in age. It is, therefore, only

Explanation of Plate 3. Palynological remains from black shale samples of the Hetang Formation. The specimens illustrated in figs 4 and 6 are sphaeromorph acritarchs (Leiosphaeridium or Lophosphaeridium sp.). 1, XTW-A-1-8(2)(15-5x2)-(659-855); 2, XTW-C-1-2-(15-44)-(406-052); 3, XTW-c-1-2(2)-(15-48x2)-(331-649); 4, XTW-c-1-2(2)-(15-50x2)-(361-545); 5, XTW-c-1-2(2)-(15-44)-(315-685); 6, XTW-C-1-2-(15$54 \times 2)-(311-325)$; 7, XTW-C-1-2-(15-21(2))-(862-837); 8, XTW-c-1-2(2)-(15-54x2)-(285-673); 9, XTW-c-1-2(2)-(15-34x2)-(502-83). 
slightly older than the Botomian level of the Altai Mountains (Siberia) from which the oldest confirmed Radiolaria are reported to date (Obut \& Iwata, 2000; Pouille et al., 2011).

(2) Although the radiolarian specimen illustrated by Braun et al. (2007a) should be considered as contamination, a number of indications (i.e. size, recrystallized hollow shell with residual spines) on some spherical siliceous microfossils observed in both residues and thin sections argue for the possible presence of radiolarians towards the top of Member ' $a$ ' of the Hetang Formation.

(3) The Ge/Si ratio of the studied black cherts and shales suggests strongly that silica in the Hetang Formation is of biogenic origin, thus providing evidence for the oldest (to our knowledge) pelagic siliceous sediments known so far.

\section{ACKNOWLEDGEMENTS}

Lei Zhang was funded by the European ERASMUS MUNDUS external windows programme for a year at the University Lille 1. This study was also supported by the China Geological Survey (Project No. G121911). We are grateful to Xianzhi Huang and Yong Lei for their help in the field. We thank S. Regnier for thin section preparation, C. Cesari and L. Debauvais for palynological and powder preparations, P. Recourt and S. Vantalon for help with the SEM and Raman spectroscopy. Constructive remarks by P. Dumitrica and J. Maletz improved the initial manuscript.

\section{Manuscript received 30 January 2013 Manuscript accepted 25 April 2013}

Scientific Editing by Alan Lord

\section{REFERENCES}

Bass, D., Moreira, D., Purificacion, L. et al. 2005. Polyubiquitin insertions and the phylogeny of Cercotoa and Rhizaria. Protist, 156: 149-161.

Blair Hedges, S., Chen, H., Kumar, S., Wang, D.Y.C., Thompson, A.S. \& Watanabe, H. 2001. A genomic timescale for the origin of eukaryotes. BMC Evolutionary Biology, 1. http://dx.doi.org/10.1186/1471-2148-1-4

Braun, A. \& Chen, J. 2003. Plankton from Early Cambrian black shale series on the Yangtze Platform, and its influences on lithologies. Progress in Natural Science, 13: 777-782.

Braun, A., Chen, J.Y., Waloszek, D. \& Maas, A. 2007a. First Early Cambrian Radiolaria. In Vickers-Rich, P. \& Komarower, P. (Eds), The Rise and Fall of the Ediacaran Biota. Geological Society, London, Special Publications, 286: 143-149.

Braun, A., Chen, J.Y., Waloszek, D. \& Maas, A. 2007b. Siliceous microfossils and biosiliceous sedimentation in the lowermost Cambrian of China. In Vickers-Rich, P. \& Komarower, P. (Eds), The Rise and Fall of the Ediacaran Biota. Geological Society, London, Special Publications, 286: 423-424.

Carignan, J., Hild, P., Mevelle, G., Morel, J. \& Yeghicheyan, D. 2001. Routine analyses of trace elements in geological samples using flow injection and low pressure on-line liquid chromatography coupled to ICP-MS: A study of geochemical reference materials BR, DR-N, UB-N, AN-G and GH. Geostandards Newsletter, 25: 187-198.

Danelian, T. \& Moreira, D. 2004. Palaeontological and molecular evidence for the origin of silica secreting marine organisms. Comptes Rendus Palevol, 3: 229-236.

Dong, X., Knoll, A.H. \& Lipps, J.H. 1997. Late Cambrian Radiolaria from Hunan, China. Journal of Paleontology, 71: 753-758.

He, S. \& Yu, G. 1992. The Small Shelly Fossils from the Palaeocambrian Meishucunian Stage in Western Zhejiang. Geology of Zhejiang, 8: 1-7.
Jiao, W.F., Wu, Y.B., Yang, S.H., Peng, M. \& Wang, J. 2009. The oldest basement rock in the Yangtze Craton revealed by zircon $\mathrm{U}-\mathrm{Pb}$ age and Hf isotope composition. Science in China Series D: Earth Sciences, 52: 1393-1399.

Korovnikov, I., Sennikov, N., Danelian, T., Obut, O. \& Pouille, L. 2013. The biostratigraphic and palaeoenvironmental significance of Lower Cambrian (Botomian) trilobites from the Ak-Kaya section of the Altai Mountains (southern Siberia, Russia). Annales de Paléontologie, 99: 79-89.

Lei, Y., Servais, T., Feng, Q.L. \& He, W.H. 2012. The spatial (nearshoreoffshore) distribution of latest Permian phytoplankton from the Yangtze Block, South China. Palaeogeography, Palaeoclimatology, Palaeoecology, 363-364: 151-162.

Li, J., Servais, T. \& Brocke, R. 2002. Chinese Paleozoic arcritarch research: review and perspectives. Review of Palaeobotany and Palynology, 118: 181-193.

Lu, Y., Mu, E., Zhang, R. \& Liu, D. 1955. Cognition of Palaeozoic strata of Western Zhejiang. Geological Knowledge, 2: 1-6.

Maletz, J.2011. Radiolarian skeletal structures and biostratigraphy in the early Palaeozoic (Cambrian-Ordovician). Palaeoworld, 20: 116-133.

Maliva, R.G., Knoll, A.H. \& Siever, R. 1989. Secular change in chert distribution: a reflection of evolving biological participation in the silica cycle. Palaios, 4: 519-532.

Mao, J.W., Zhang, G.D. \& Du, A.D. 2001. Geology, geochemistry and Re-Os isotopic dating of the Huangjiawan Ni-Mo-PGE deposit, Zunyi, Guizhou province. Acta Geologica Sinica, 75: 234-243.

Murowchick, J.B., Coveney, R.M. \& Grauch, R.I. 1994. Cyclic variations of sulfur isotopes in Cambrian stratabound $\mathrm{Ni}-\mathrm{Mo}-(\mathrm{PGE}-\mathrm{Au})$ ores of southern China. Geochimica et Cosmochimica Acta, 58: 1813-1823.

Obut, O.T. \& Iwata, K. 2000. Lower Cambrian Radiolaria from the Gorny Altai (Southern west Siberia). News of Paleontology and Stratigraphy, 2-3: 33-38.

Peng, S.C., Babcock, L.E., Zuo, J.X. et al. 2009. Proposed GSSP for the base of Cambrian Stage 9, coinciding with the first appearance of Agnostotes orientalis, at Duibian, Zhejiang, China. Science in China Series D: Earth Sciences, 52: 434-451.

Pouille, L., Obut, O., Danelian, T. \& Sennikov, N. 2011. Lower Cambrian (Botomian) polycystine Radiolaria from the Altai Mountains (southern Siberia, Russia). Comptes Rendus Palevol, 10: 627-633.

Racki, G. \& Cordey, F. 2000. Radiolarian palaeoecology and radiolarites: is the present the key to the past?. Earth-Science Reviews, 52: 83-120.

Siever, R. 1992. The silica cycle in the Precambrian. Geochimica et Cosmochimica Acta, 56: 3265-3272.

Steiner, M., Li, G., Qian, Y., Zhu, M. \& Bernd, E. 2003. Lower Cambrian small shelly faunas from Zhejiang (China) and their biostratigraphical implications. Progress in Natural Science, 13: 852-860.

Steiner, M., Li, G., Qian, Y., Zhu, M. \& Erdtmann, B. 2007. Neoproterozoic to Early Cambrian small shelly fossil assemblages and a revised biostratigraphic correlation of the Yangtze Platform (China). Palaeogeography, Palaeoclimatology, Palaeoecology, 254: 67-99.

Tolmacheva, T., Danelian, T. \& Popov, L. 2001. Evidence for 15 million years of continuous deep-sea biogenic sedimentation in Early Palaeozoic oceans. Geology, 29: 755-758.

Tribovillard, N., Bout-Roumazeilles, V., Riboulleau, A., Baudin, F., Danelian, T. \& Riquier, L. 2011. Transfer of germanium to marine sediments: insights from its accumulation in radiolarites and authigenic capture under reducing conditions. Some examples through geological ages. Chemical Geology, 282: 120-130.

Won, M.Z. \& Below, R. 1999. Cambrian Radiolaria from the Georgina Basin, Queensland, Australia. Micropaleontology, 45: 325-363.

Xiao, S., Hu, J., Yuan, X., Parsley, R.L. \& Cao, R. 2005. Articulated sponges from the Lower Cambrian Hetang Formation in southern Anhui, South China: their age and implications for the early evolution of sponges. Palaeogeography, Palaeoclimatology, Palaeoecology, 220: 89-117.

Xue, Y. \& Yu, C. 1979. Petrological characteristics and sedimentary environment analysis of the Hetang Formation, Lower Cambrian of Western 
The Lower Cambrian biotic and geochemical record of the Hetang Fm., China

Zhejiang and Northeast Jiangxi Province. Acta Stratigraphica Sinica, 3: 283-292.

Yang, A., Zhu, M. \& Zhang, J. 2008. Chronostratigraphy of Cambrian Huangboling and Hetang Formations in Southern Anhui and Western Zhejiang. Journal of Stratigraphy, 32: 343-352. [In Chinese, with English abstract.]

Yang, R., Zhu, L., Gao, H., Zhang, W., Jiang, L., Wang, Q. \& Bao, M. 2005. A study on characteristics of the hydrothermal vent and relat- ing biota at the Cambrian bottom in Songlin, Zunyi county, Guizhou Province. Geological Review, 15: 481-492.

Yue, Z. \& He, S. 1989. Early Cambrian Conodonts and Bradoriids from Zhejiang. Acta Micropalaeontologica Sinica, 6: 289-300.

Zhou, C. \& Jiang, S. 2009. Palaeoceanographic redox environments for the lower Cambrian Hetang Formation in South China: Evidence from pyrite framboids, redox sensitive trace elements, and sponge biota occurrence. Palaeogeography, Paleoclimatology, Palaeoecology, 271: 279-286. 


\section{For full details see the Online Bookshop www.geolsoc.org.uk/bookshop}

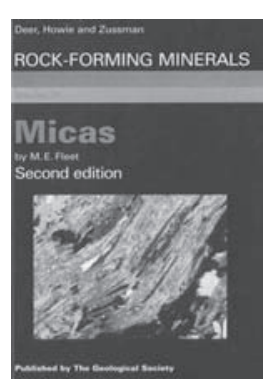

\section{Rock-Forming Minerals Vol. 3A: Micas, Second Edition}

By M.E. Fleet

In this extensive and comprehensive review, the mica sections of Volume 3 have been completely rewritten, reorganized and greatly expanded. The text covers such aspects as crystal structure, crystal chemistry, chemical spectroscopy, stability and phase relations, redox behaviour and weathering, stable isotope geochemistry, geochronology, and igneous and metamorphic geochemistry and petrology.

ISBN: 978-1-86239-142-0 | Hardback | 780 pages | Publication date: 23 February 2004

List price: £125.00 Fellow's price: £62.50 Other societies price: $£ 75.00$ Online Bookshop Code: RFM3A

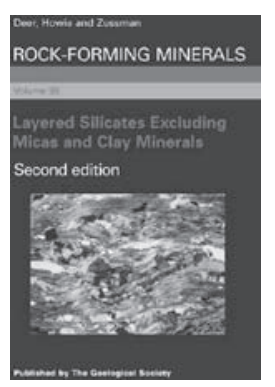

\section{Rock-Forming Minerals Vol. 3B: Layered Silicates: Excluding Micas and Clay Minerals, Second Edition}

By W.A. Deer, R.A. Howie, J. Zussman

This extensive revision deals with the minerals talc, pyrophyllite, chlorite, serpentine, stilpnomelane, zussmanite, prehnite and apophyllite. The text has been completely rewritten and very much expanded to take account of the many advances that have been made in all aspects of the Earth sciences, not least mineralogy.

ISBN: 978-1- 86239-315-8 | Hardback | 320 pages | Publication date: 6 March 2009

List price: $£ 100.00$ Fellow's price: $£ 50.00$ Other societies price: $£ 60.00$ Online Bookshop Code: RFM3B

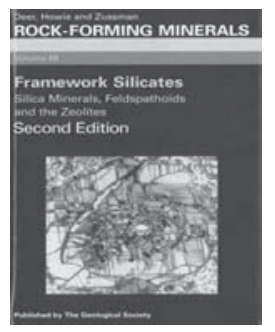

\section{Rock-Forming Minerals Vol. 4B: Framework Silicates, Second Edition}

By W.A. Deer, R.A. Howie, W.S. Wise and J. Zussman

This major revision takes place 40 years after publication of the first edition, and deals with feldspathoids, silica minerals and zeolites. The text has been completely re-written and very much expanded, incorporating the advances in knowledge and understanding arising from the new and improved techniques for the study of minerals that have developed.

ISBN: 978-1-86239-144-4 | Hardback | 982 pages | Publication date: 18 May 2004

List price: £125.00 Fellow's price: £62.50 Other societies price: $£ 75.00$ Online Bookshop Code: RFM4B

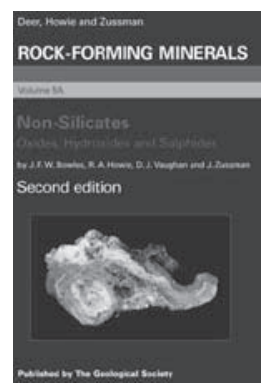

\section{Rock-Forming Minerals Vol. 5A: Non-Silicates: Oxides, Hydroxides and Sulphides, Second Edition}

By J.F.W. Bowles, R.A. Howie, D.J. Vaughan and J. Zussman

A completely rewritten and much expanded new edition of the part of Volume 5 of Rock-Forming Minerals dealing with the oxide, hydroxide and sulphide minerals. It is an essential reference work for researchers, teachers and advanced students of mineralogy, petrology, geochemistry, mining, gemmology and related fields.

ISBN: 978-1- 86239-315-8 | Hardback | Pages: 920 | Publication date: 16 June 2011

List price: $£ 140.00$ Fellow's price: $£ 70.00$ Other societies price: $£ 84.00$ Online Bookshop Code: RFM5A

Order from:

www.geolsoc.org.uk/bookshop

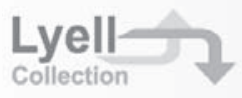

The Geological Society's Lyell Collection: journals, Special Publications and books online. For more information visit www.geolsoc.org.uk/LyellCollection 